\title{
CORRESPONDENCE
}

\section{Bad BBC Science}

Sir,-Since I advised on the Horizon programme "Science is Dead-Long Live Science" variously described in your leader (Nature, 241, $490 ; 1973$ ) as "disastrous", "witless", and "dangerously infected with heresy", I would be grateful for the opportunity to make a few comments.

First, I must remark on the distressingly high proportion of gross errors of perception on which your writer based his judgments. The Vietnam films were very far indeed from "the most gruesome of the gruesome"; the "defoliant" scientist was interviewed but not the "napalm" scientist; nowhere was there a claim that science made the Vietnam war possible; the scientistturned-printer was not "offended" by the FBi, but described quite clearly how he was hounded out of his job; the interview in West Virginia had as its whole point the complete corruption of the local government by the strip-miners and the effective disenfranchisement of the public; Jonathan Beckwith neither gave alarming tales of genetic engineering nor said when civilization would end ; the New Alchemist made no claim to secret knowledge ; and it was a quite different group who have gone over to Sun worship.

Perhaps there were some deeper failings in presentation that enabled your reviewer to become so confused. If so, I and the producers would be very grateful for help. It seemed abundantly clear to us that each of the very different sorts of scientists presented in the programme were a small minority-the general indifference at the AAAS meeting was, we thought, a sufficient reminder of this. We thought also that the difficulties and contradictions in each reaction, systematically and sympathetically described by Beckwith, were made clear in nearly every case.

If I were to help in modifying the programme for a re-issue, I would start by putting more emphasis on one particular still shot. This is of a proud advertisement by North American Rockwell. It describes their development work on the B-1 bomber, the planned successor to the B-52 of saturation-bombing fame. Their triumphant slogan is "North American Rockwell-where Science Gets Down to Business". This phrase, so cleverly combining a straight description with an American idiom, has rich overtones in the political and moral dimensions. I strongly suggest that your reviewer reflect on that slogan; from that could come an appreciation of what the programme was all about.

Finally, I hope that your reviewer will, on reconsideration, regret that personal sneer at the physicist persecuted by the FBI, and also the most unfortunate arguments on the responsibilities of civil servants by which the reviewer justified himself. This lent neither strength nor dignity to his criticisms of the programme, and a retraction and apology would seem appropriate. Yours faithfully, J. R. Ravetz

Department of Philosophy, University of Leeds

SIR,--It is unfortunate that your attack (Nature, 241, 490; 1973) on the BBC for irrationality in science programmes was itself so irrational. It used a device much favoured in debating societies, but surely to be abjured by a scientist with any pretensions to objectivity, namely falsely accusing the opposition of having made a certain statement and then proceeding to demolish it.

In stating that the Horizon programme "Science is Dead-Long Live Science" implied an absurdity, namely that the profession of science, not the politicial climate, made the Vietnam war possible, you underestimate the average viewer's intelligence and good sense and negate your own. "Implication" is in the brain of the beholder, and I for one caught no shadow of such an implication. The programme was making a quite different point, clear enough to an unbiased viewer, that the scientific weapons being used were based on investigations made for peaceful ends, not specifically developed by government scientists aware of their mission. Almost all your allegations are similarly off beam. To take just one more example, it is simply not true that the programme used Beckwith "as an excuse for alarming its audience with tales of genetic engineering". The programme was, in fact, making exactly the opposite point, namely that when Beckwith tried to interest the community in a (note) rational consideration of the possible consequences of chemical synthesis of a gene, he was so distressed by the alarmist furore that his action set off in the popular press that he desisted.

What impels me to write, rather than ignore such ill-founded criticism, is that your editorial castigated a courageous and original attempt to explore a real and important facet of the scientific world, namely the constant and insidious worry about the hideous uses to which the most innocent scientific discovery may eventually be put. What gives Horizon programmes their continuing vitality is precisely these qualities of courage and originality. It is easy to make programmes which are aimed at blinding the public with science and how marvellous it all is; it is easy too (as your editorials frequently demonstrate) to rail at the Establishment, and even easier to ridicule the thoughtful and rebellious young. It is not so easy to describe, quietly and objectively, an uncomfortable phenomenon in our midst-scientific heretics-and to discuss without hysteria a profound problem that troubles us all ; whether to continue to wrest secrets from nature that may be perverted to evil ends. In my opinion, this Horizon programme did just that, and did it extraordinarily well. Yours faithfullly,

F. PETER WOODFORD

\section{Creation vs Evolution}

SIR, - The decision of the State Board of Education in California to preach the doctrine of creation rather than to teach the theory of evolution in the state high schools has not only created a stir among the intellectuals of the world, but thrown a challenge to the entire scientific world to dispel myths about certain phenomena of the universe which are considered as status symbols of transcendental edicts of present day society. The letters of G. Vanderkooi, E. C. Lucas, and A. R. Smith (Nature, 240, 365-366; 1972) and A. J. J. Hayward (ibid., 492) support the existence of supernatural power which controls the universe. It is unfortunate that a plant taxonomist, A. R. Smith, could not visualize the process of evolution, which he ridiculed as a "tissue of lies". I, as a botanist, do not agree with him.

The concept of evolution is based on scientific facts, and reveals the truth of nature, although problems such as the origin of life and man's origin are still open for further studies. It is necessary to realize that evolution does not always mean the tracing out of the ancestry of organisms, but as a natural process that has been operating in the universe. Within the living organisms it is an essential natural process taking place as a result of interaction between the genomes and the ever changing environment. Genetic recombination, mutation and selection are the main wheels on which the vehicle of evolution is 
proceeding to its never ending destination. Vanderkooi, who argued that there is no evidence to account for the process of macroevolution, is probably unaware of the fact that adaptive radiation is responsible for the evolution of higher taxa. True, there are certain forces in nature which cannot be readily explained in terms of science. This inability of science has often been taken up as a proof of the existence of a creator. It is increasingly evident that selection pressures direct the process of evolution. Although it is very difficult to interpret what is exactly a selection pressure, it is not ruled out that a scientist may come out with a model which unearths the hidden secret of selection pressures.

Vanderkooi pointed out that bacterial cells are as complex as any other living cells of the organism, and as such they cannot be considered as the primitive living organisms from which other organisms have been evolved. It is possible that all living organisms might have evolved from some primitive form (monophyletically), and further diversification within the evolved groups might have resulted in the evolution of different groups polyphyletically. The closer resemblance of the amino-acid sequence in cytochrome-C of wheat to that of animals rather than to cytochrome-C of fungi favours the polyphyletic origin.

On the other hand, the concept of creation is nominalistic, and has no place in scientific thinking. The doctrine of creation is a man-made catastrophe, and if it is continued to be advocated by man as a basic conceptual controversy, it is just like putting the clock back and will hamper the advancement of humanity.

To denounce the teaching of the theory of evolution, which has been nurtured by the cumulative efforts of hundreds of scientists for about 100 years, is to deny the legitimate rights of society to learn and understand the reality of the nature and the role of man as part of the natural and social world. If it is done it will become one of the greatest tragedies and educational failures of our time. Yours faithfully, C. R. BABU

Department of Botany,

University of Delhi,

Delhi-7

\section{Use of IS, TWA and ILWS}

SIR,- The present author (PA) is writing to request the increased use in Nature of initial-letter-word-substitution (ILWS). Unpublished studies of the PA show that the superficial-scientific-appearance-rating (SSAR) of a paper is most effectively increased by impersonal style (IS), technical-word- amplification (TWA) and ILWS. There is, moreover, a highly significant positive correlation between the SSAR of a paper and its peer-esteem-rating (PER). The PA hopes that Nature will cooperate in raising the PER of its contributors by encouragement of ILWS, as well as acceptance of IS and TWA. Yours faithfully,

J. M. BARRY

Department of Agricultural Science, University of Oxford,

Parks Road, Oxford OX1 3PF

\section{Between Bees}

SiR,-

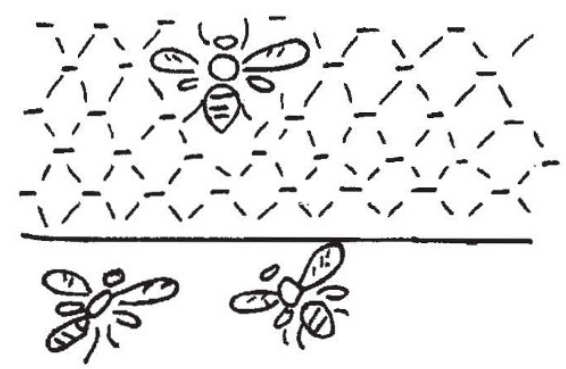

He's saying, "Go to Hive 2 tomorrow.

They're killing bees at Hives 1 and 3". ${ }^{1}$

Yours faithfully,

F. J. MaLoney

Livermore,

California

1 Nature, 241, 171 (1973).

\section{Obituary}

\section{Dr Stephen R. Pelc}

Stephen R. Pelc, who died suddenly on February 6 , at the age of 65 , was internationally famous for his pioneer work on the techniques of autoradiography and for his use of these techniques in cellular biological research. He graduated from the University of Vienna and published his first work from the Institut für Radiumforschung in 1931. In 1938 he came to Britain and, after serving in the forces during the war, he restarted his scientific work at the Hammersmith Hospital, London, first as a hospital physicist and then as a member of the MRC Radiotherapeutic Research Unit.

There he began his studies on the action of ionizing radiations on photographic film which led to his development of stripping-film autoradiography for obtaining high resolution autoradiographs of sections of biological material, work done with the enthusiastic collaboration of Dr (now Professor) I. Doniach and under the scientific directorship of the late Dr L. H. Gray.
Dr Pelc had the idea of using pliable photographic film stripped from Ilford stripping plates which were, at that time, being used in industry for other purposes. Kodak then produced the AR10 and AR50 stripping film to his requirements, giving far greater resolution, so that these have now become the standard materials for this form of autoradiography. Initially, when ${ }^{131}$ I was the most readily available isotope, this technique was used by Professor Doniach and himself for studies on the thyroid gland under various physiological conditions. As other radioactive isotopes became available, however, the applications of autoradiography expanded rapidly so that it is now used throughout the world on many varied biological and medical research problems.

$\mathrm{He}$ is most famous for work begun in the early nineteen-fifties with Dr Alma Howard. By incorporating ${ }^{32} \mathrm{P}$ into dividing cells and removing all but the DNA by acid hydrolysis he was able to time the incorporation of ${ }^{32} \mathrm{P}$ into nuclear DNA. He showed that DNA synthesis did not occur after prophase, as had been believed previously from staining evidence, nor did it occur continuously throughout interphase. $\mathrm{He}$ and Howard showed that, for each type of nucleus, there was a particular period of interphase, which he called the "S" (synthesis) stage, during which the DNA content doubled; this DNA was stable and became divided equally into the two daughter nuclei. Before and after the "S" there was a gap in his knowledge of what metabolic processes occurred in the nuclei and, understandably, he named these " $G_{1}$ " and " $G_{2}$ ". The period of interphase therefore could be extended if $G_{1}$ or $G_{2}$ became prolonged. These results were confirmed and extended considerably with the introduction of other isotopically labelled DNA and RNA precursors, particularly those labelled with ${ }^{3} \mathrm{H}$.

Thus he laid the basis for the study of cell kinetics based on the timed uptake of isotopically-labelled precursors and their distribution into the cells derived from the initial, labelled mitotic cell. Of particular importance were his studies on the small intestine, in which 